\title{
Test Not Ordered
}

National Cancer Institute

\section{Source}

National Cancer Institute. Test Not Ordered. NCI Thesaurus. Code C131119.

An indication that a test was not ordered. 